w tym zakresie, w szczególności w świetle zmian, jakie wprowadza nowa ustawa Prawo geologiczne i górnicze. Z kolei Paweł Lis, reprezentujący Państwowy Instytut Geologiczny w Warszawie (Zakład Kartografii Geologicznej Struktur Wgłębnych), przybliżył zasady gromadzenia przez Instytut danych na temat zasobów gazu łupkowego w Polsce. Szczególną uwagę słuchaczy skupiła Hanna Dzikowska, Regionalny Dyrektor Ochrony Środowiska w Gdańsku, która szczegółowo omówiła kwestię nadzoru sprawowanego przez Dyrekcję Ochrony Środowiska nad działaniami przedsiębiorstw poszukujących gazu łupkowego.

Konferencja wzbudziła szerokie zainteresowanie w środowisku akademickim Poznania. Wśród licznych słuchaczy znaleźli się nie tylko pracownicy naukowi oraz studenci z Wydziału Prawa i Administracji oraz z Instytutu Geologii UAM, lecz również osoby z innych wydziałów Uniwersytetu, a także z innych poznańskich uczelni. Tezy prezentowane przez przedstawicieli środowiska prawniczego, odnoszące się do konieczności zagwarantowania należytego wpływu państwa na procesy poszukiwania i wydobywania gazu łupkowego, a także odpowiedniego nadzoru nad stanem wód gruntowych i podziemnych, okazały się w dużej mierze zbieżne z tezami prezentowanymi przez przedstawicieli nauk geologicznych. Naukowym rezultatem konferencji będzie publikacja przygotowywana przez jej organizatorów.

\title{
$X$ SESJA NAUKOWA MŁODYCH PRACOWNIKÓW NAUKOWYCH WYDZIAŁU PRAWA I ADMINISTRACJI UAM Poznań, 6 grudnia 2011 r.
}

W dniu 6 grudnia 2011 r. w Collegium Iuridicum Novum Wydziału Prawa i Administracji Uniwersytetu im. Adama Mickiewicza w Poznaniu odbyła się X Sesja Naukowa Młodych Pracowników Naukowych Wydziału.

Sesja jest wydarzeniem cyklicznym, które od 2003 r. jest stałym elementem kalendarza wydarzeń naukowych Wydziału Prawa i Administracji UAM, będącym kontynuacją (między innymi poprzez zachowanie ciągłości w numeracji kolejnych edycji) przedsięwzięcia zapoczątkowanego w 1955 r. ${ }^{1}$ Od 2003 r. publikacje zawierające teksty referatów wygłoszonych podczas Sesji ukazuje się pod tytułem Prawo wobec wyzwań wspótczesności $i^{2}$. Tytuł ten wskazuje na jeszcze jeden cel Sesji, którym jest poruszanie problemów stanowiących aktualne wyzwania dla współczesnej nauki prawa, a jednocześnie wychodzących naprzeciw zapotrzebowaniu praktyki oraz wpisujących się $\mathrm{w}$ bieżące wydarzenia i problemy społeczne.

Obrady X Sesji otworzył prof. UAM dr hab. Tomasz Sokołowski Dziekan Wydziału Prawa i Administracji UAM, który wyraził zadowolenie z faktu, że Sesja niezmiennie przyciaga chętnych do wzięcia w niej udziału doktorów i doktorantów Wydziału. Podkreślił przy tym, że przydatności tego projektu dowodzi obecność wśród dzisiejszych młodych profesorów Wydziału autorów referatów opublikowanych w poprzednich tomach Prawa wobec wyzwań wspótczesności, których nazwiska i dorobek naukowy niejednokrotnie są już dobrze znane ogólnopolskiej nauce prawa.

Sesja podzielona była na trzy panele dyskusyjne. Pierwszy z nich dotyczył wybranych problemów prawnych związanych z trwającą od 1 lipca do 31 grudnia 2011r. prezydencją Polski w Radzie Unii Europejskiej. W jego ramach poruszono zagadnienie deficytu demokracji w Unii Europejskiej w aspekcie instytucjonalnym na przykładzie Parlamentu Europejskiego, problematykę stosunków traktatowych Unii Europejskiej $\mathrm{z}$ państwami trzecimi w świetle Traktatu lizbońskiego oraz europeizacji prawa rodzinnego $\mathrm{w}$ odniesieniu do prawa polskiego.

${ }^{1}$ Zob. sprawozdanie z IV Sesji: „Ruch Prawniczy, Ekonomiczny i Socjologiczny” 2004, z. 2, s. 302.

2 Zob. W. Dajczak, rec. Prawo wobec wyzwań wspótczesności, red. B. Guzik, N. Buchowska, P. Wiliński, t. V, Poznań 2008, ss. 486, „Ruch Prawniczy, Ekonomiczny i Socjologiczny” 2009, z. 3, s. 221-223. 
Panel drugi poświęcony został trwającej w Polsce i dokonywanej sukcesywnie reformie prawa prywatnego. Problemami wiodącymi były tu zagadnienia dotyczące nowych instytucji wprowadzonych do polskiego porządku prawnego, na przykład rozważano potrzebę nowelizacji niektórych przepisów Kodeksu spółek handlowych i scharakteryzowano pozycję stron i uczestników postępowania w procesie dowodzenia przed sądem cywilnym pierwszej instancji.

Panel trzeci dotyczył niezmiennie aktualnych problemów z zakresu ochrony praw jednostki. Zaprezentowano w nim rolę międzynarodowej ochrony praw człowieka w dobie zmian klimatycznych, a także środków przymusu bezpośredniego w kontekście gwarancji konstytucyjnych, przedstawiono wpływ orzecznictwa Trybunału Konstytucyjnego na postępowanie sądowoadministracyjne, scharakteryzowano pozycję ustrojową Rzecznika Praw Obywatelskich RP.

Każdy z paneli kończyła otwarta dyskusja plenarna nad zagadnieniami poruszonymi $\mathrm{w}$ referatach. W dyskusjach wzięli udział pracownicy naukowi Wydziału, studenci i referenci.

Wydanie publikacji zawierającej teksty referatów z X Sesji Naukowej Młodych Pracowników Nauki Wydziału Prawa i Administracji UAM jest przewidziane w pierwszej połowie 2012 r. Podczas Sesji zaś można było się zapoznać z tomem VII publikacji Prawo wobec wyzwań wspótczesności, zawierającym referaty wygłoszone podczas poprzedniej edycji Sesji, która odbyła się w grudniu 2010 r.

Z kronikarskiego obowiązku odnotować również należy, że organizatorami X Sesji byli prof. UAM dr hab. Paweł Wiliński, dr Natalia Buchowska, mgr Bartosz Guzik i mgr Patryk Filipiak.

Bartosz Guzik 